\title{
Gallus gallus domesticus: immune system and its potential for generationof immunobiologics
}

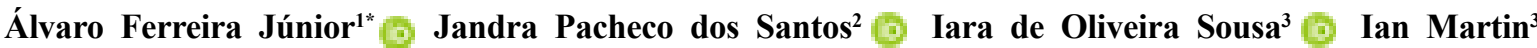 Endrigo Gabellini Leonel Alves $^{3} \odot$ Isabel Rodrigues Rosado ${ }^{3}$}

'Escola de Veterinária e Zootecnia, Medicina Veterinária Preventiva, Universidade Federal de Goiás (UFG), 74.690-900, Goiânia, GO, Brasil E-mail: alvaro.ferreira@ufg.br. "Corresponding author.

${ }^{2}$ Programa de Pós-graduação em Ciências Veterinárias, Universidade Federal de Uberlândia (UFU), Uberlândia, MG, Brasil.

${ }^{3}$ Programa de Pós-Graduação em Sanidade e Produção Animal nos Trópicos, Universidade de Uberaba (UNIUBE), Uberaba, MG, Brasil.

ABSTRACT: Gallus gallus domesticus 'immune system is a promising tool for generation of antibody-based immunobiologics. Immunoglobulin $Y(\operatorname{IgY})$ is extracted from egg yolk and has equivalent functions to mammal's IgG antibody. Avian immune system can be stimulated to produce a high-quality antibody repertoire. In this review, we present an overview of avian immune system emphasizing IgY and its applications as an immunobiologic.

Key words: avian lymphoid tissues; avian immune response; IgY antibody.

Gallus gallus domesticus: sistema imunológico e seu potencial para geração de imunobiológicos

RESUMO: O sistema imunológico de Gallus gallus domesticus é uma ferramenta promissora para a geração de imunobiológico a partir de anticorpos. A imunoglobulina Y (IgY) é extraída da gema do ovo e apresenta funções equivalentes ao anticorpo IgG dos mamíferos. O sistema imune aviário pode ser estimulado para produzir um repertório de anticorpos de alta qualidade. Nesta revisão apresentamos aspectos gerais do sistema imune aviário enfatizando o IgY e suas aplicações como um imunobiológico

Palavras-chave: tecidos linfoides aviários; resposta imune aviária; anticorpo IgY.

\section{INTRODUCTION}

Chicken (Gallus gallus domesticus) has made valuable contributions to our understanding of immunology. However, the "chicken is not a mouse with feathers" (by JIM KAUFMAN (KAISER, 2012)), and 'the hens' immune system differs from mammals' in various ways" (SCHADE et al., 2001). In this context, important differences exist, especially in the diversity of the lymphoid tissue. For instance, the bursa of Fabricius is present in hens but not in mammals. The major blood antibody class present in hens is immunoglobulin $\mathrm{Y}(\operatorname{IgY})$, whereas that in mammals is IgG. IgE antibodies are absent in the hens' immune system. Additionally, the transference of maternal antibodies in the hen occurs by egg yolk absorption, and by transplacental passage in mammals.

One aspect that hens and mammals have in common, is the presence of both, the innate as well as the acquired immune response. These animal groups possess immune cells and molecules. Among these immune cells are the dendritic cells (DC), macrophages, and lymphocytes. With regard to the hens' immunity, the crucial function of these molecules as signaling proteins has been demonstrated. They are also known as cytokines. Besides, a lytic protein system named the complement system protects the host by both, innate and acquired immune response mechanisms.

Interestingly, according to phylogenetic analysis, hens developed before mammals. In addition, the avian immune system is genetically simpler than that of the mammalian immune system. The former can mount a robust immune response against a wide range of antigenic targets. Corroborating this robustness, the avian repertoire of antibodies has an elevated number of antigen binding combinations. These have been achieved 
by the antibodies' gene recombination and gene conversion. In conclusion, the efficacy of the hens' immune system has been proven in its elaborate defenses against aggressors by different mechanisms. The IgY antibodies are a valuable tool in the hens' immune system, and, a promising immunobiological reagent. Hence, these can be tapped as an alternative for the mammals' IgG antibodies.

\section{Lymphoid Tissues}

Chicken has made valuable contributions to our understanding of immunology (KAISER, 2012). The avian and mammal immune systems are organized into groups of immune cells, such as the T cells and B cells, and are homed into organized lymphoid tissues, which are strategically positioned to protect the host (BOEHM et al., 2012; ROSTAMI et al., 2018). Functionally, the lymphoid tissue has been classified into the primary lymphoid tissue, such as the thymus and bursa of Fabricius, and the secondary lymphoid tissue, such as the spleen (Figure 1) (MADEJ et al., 2015; SUN et al., 2016; IFRAH et al., 2017).

The hens' primary lymphoid tissue includes the thymus and bursa of Fabricius (BOEHM et al., 2012). The thymus is located at the ventral neck region and the bursa of Fabricius is reported at the top of the cloacal region (SUN et al., 2016; IFRAH et al., 2017). Primary lymphoid tissue works by selecting lymphocytes such as the T cells (thymus-dependent cells) and the B cells (bursa of Fabricius-selected cells) for an appropriate immune response and avoiding autoimmunity (SUN et al., 2016; IFRAH et al., 2017). The $\mathrm{T}$ and $\mathrm{B}$ cell precursors are generated by the lymphoid stem cells in the bone marrow (BOEHM et al., 2012).

The bursa of Fabricius is a lymphoid tissue that is absent in the immune system of mammals, as a consequence of the species' evolution (Figure 1) (BOEHM et al., 2012). After puberty, in the hens and mammals, the primary lymphoid tissue is involuted by the effects of the sex hormones.

The selected $\mathrm{T}$ and $\mathrm{B}$ cells, leaving the primary lymphoid tissue, move forward to their defense position in the secondary lymphoid tissue, such as the spleen and mucosa-associated lymphoid tissue (MALT) (LANNING \& KNIGHT, 2015; MADEJ et al., 2015; SEPAHI \& SALINAS, 2016). Also, they are present in parenchyma, the bursa of

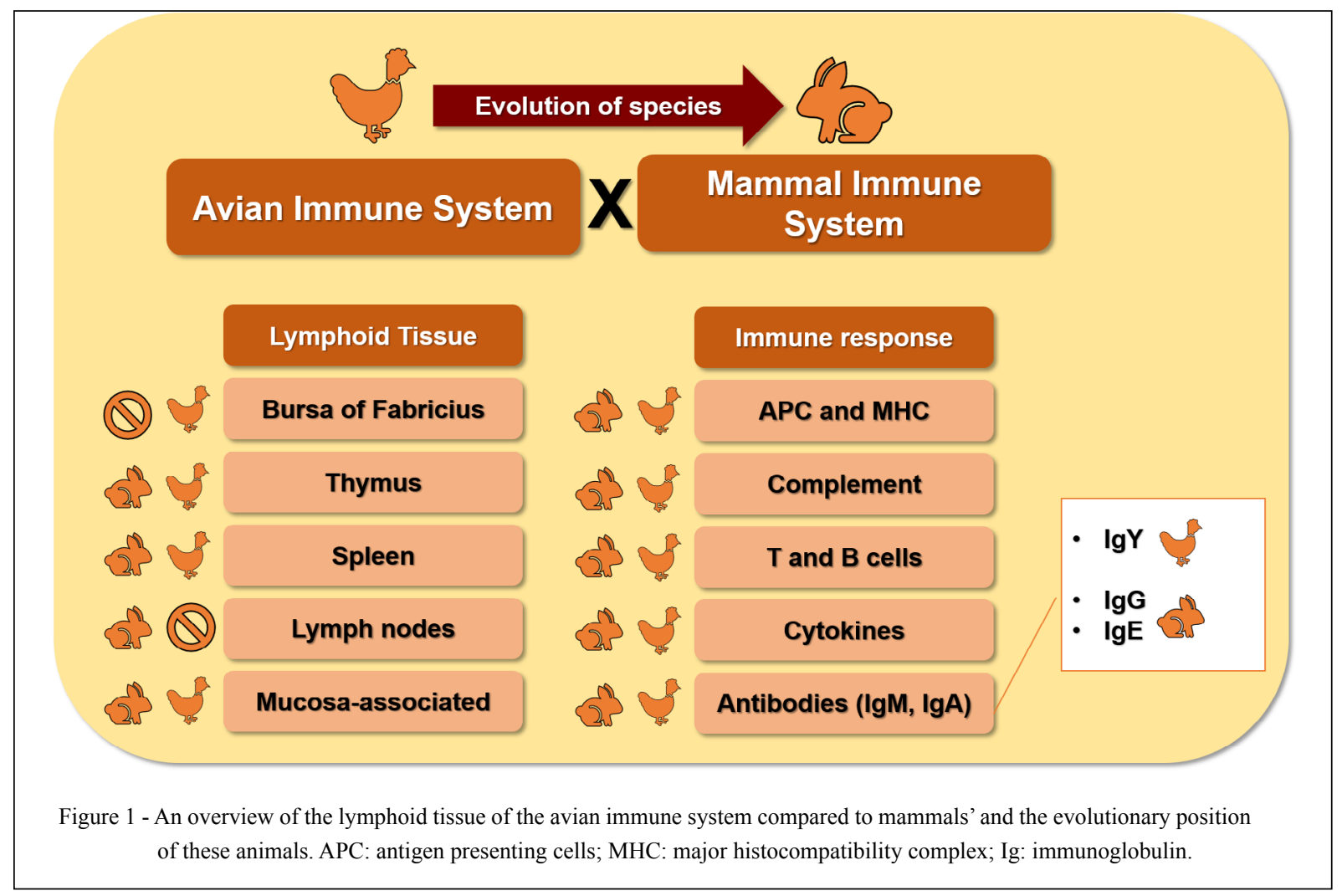

Ciência Rural, v.48, n.8, 2018. 
Fabricius, and the bone marrow tissue (MADEJ et al., 2015). Peripheral lymphoid tissue has been established as the site for the generation of an immune response following contact with a pathogen. The spleen is a capsulated tissue reported in abdominal cavity, close to the stomach (ZHANG et al., 2015), while the MALT is a lymphoid tissue scattered throughout the body, on surfaces, such as the mucosa of the digestive system and the eyes (Harderian glands) (VAN GINKEL et al., 2012; GURJAR et al., 2013), the respiratory system, and skin (SMIALEK et al., 2011; LANNING \& KNIGHT, 2015; SEPAHI \& SALINAS, 2016). Some peripheral lymphoid tissue is absent in the avian immune system, such as the lymph nodes, (Figure 1), however, there are lymphoid aggregates, such as Meckel's diverticulum and cecal tonsils (BOEHM et al., 2012; HEIDARI et al., 2015). The apparent absence of lymphotoxin genes might explain the lack of lymph nodes in hens, because these genes are crucial to lymph node formation in mammals (KAISER, 2012).

The health of the reproductive tract is important for the formation and production of high quality and hygienic eggs (YOSHIMURA $\&$ BARUA, 2017). The hen ovary and oviduct have lymphoid tissue that contains populations of immunocompetent cells such as macrophages and lymphocytes. Influx of immune cells increases with hen maturity and decreases with aging. The ovary's parenchyma and the oviduct's lamina propria express TLR (Toll-like receptor) molecules, triggering the production of pro-inflammatory cytokines and chemokines, and defensin molecules (YOSHIMURA \& BARUA, 2017).

Regarding the lymphocyte position in the secondary lymphoid tissue, the $\mathrm{T}$ cells are reported close to the B cells, in a location called the germinal center. Following contact with pathogens, the spleen is enlarged in size by hyperplasia tissue, in a process called splenomegaly. Lymphocyte hyperplasia has been found in MALT as well. The germinal center is the site that effectively produces the avian antibodies.

\section{Avian Immune System}

Avian immune response is divided in two arms, the innate immune response and the acquired immune response (JEURISSEN et al., 2000; KAISER, 2012). The former involves the quick activation of immune mechanisms, such as the acute inflammatory reaction, which includes cells and molecules such as macrophages and the complement system (GUO et al., 2008)2008. Conversely, the acquired immune response is delayed and characterized by antibody production (Figure 2) and immune memory (PEI \& COLLISON, 2005; SINGH et al., 2010). It has been emphasized that the innate immunity does not develop an immune memory like that observed in acquired immunity (GUO et al., 2008)2008. Recently, it has been demonstrated that some differences occur in populations of immunocompetent cells between various hens breeds (BÍLKOVÁ et al., 2017).

The innate immune response starts when the sentinel cells, such as the dendritic cells and macrophages, trap non-self-compounds (antigens) (QURESHI et al., 2000; DE GEUS \& VERVELDE, 2013; NAGY et al., 2016). These sentinel cells recognize the pathogen-associated molecular patterns (PAMPS) by their pathogen recognition receptors (PRR) such as the Toll-like receptor (TLR), after which they trigger an acute inflammatory reaction (QURESHI et al., 2000; NANG et al., 2011; GRUEBER et al., 2014). Pathogens are classified according to their growth environment, as extracellular pathogens, such as certain bacteria, or intracellular pathogens, like viruses. Neutrophils and eosinophils are absent in hens and the latter is replaced by heterophils in the avian immune system (KAISER, 2012; MUKHERJEE et al., 2016).

Following the pathogen trapping, the sentinel cells must process the protein antigens in the antigenicity determinant regions, also called the epitopes (Figure 2) (WANG et al., 2016). There are different antigen processing pathways, such as the lysosomal pathway for extracellular pathogens, and the proteasome pathway for intracellular pathogens (Figure 2) (BLUM et al., 2013). Although both antigen processing pathways produce epitopes, the antigen processing by the lysosome enzymes generate a larger peptide sequence than the enzymatic proteasome pathway (HASSELGREN \& FISCHER, 1997).

In the next step, following the generation of epitopes, peptide binding to the major histocompatibility complex (MHC) molecules occurs, followed by antigen presentation to the $\mathrm{T}$ cells (LIVERSIDGE \& FORRESTER, 1992; MILLER \& TAYLOR, 2016). The class I MHC molecules bind to the generated epitopes by the proteasome pathway (KAUFMAN, 2015), whereas the class II MHC docking peptides are sourced from the lysosome's antigen processing pathway (PARKER \& KAUFMAN, 2017). Hens possess two class I genes and two class II genes compared to the 300 genes of the mammals' MHC. This "minimal essential MHC" has some consequences for hens to mount an immune response against 
certain pathogens (KAUFMAN, 2000). In this context, there is a higher chance for this compact and simple avian MHC does not present a give protective epitope during the antigen presentation to T (KAUFMAN, 2000).

Antigen presenting cells (APC), such as the dendritic cells (DC) and macrophages, present the epitope-MHC to the lymphocyte cells, such as T lymphocytes (Figure 2) (BECKER, 2003). The T cells, using their antigen receptor complex (TCR), bind to the epitopes and recognize the MHC molecules. This recognition is carried out by complementary receptors, such as $\mathrm{CD} 8$ and $\mathrm{CD} 4$, which recognize the self-class I MHC and class II MHC molecules, respectively. Therefore the $\mathrm{T}$ cells are named the MHC-restricted lymphocytes (Figure 2) (XIAO et al., 2017). Intracellular specialized T CD8 cells are called the cytotoxic lymphocyte cells (CTL), and cytokines producing T CD4 cells are called helper T cells (Th) (SHARMA \& TIZARD, 1984; KOGUT, 2000; MELIEF, 2003; ARUN et al., 2011).

T-helper cells produce signaling proteins named cytokines (Figure 2) that orchestrate the acquired immunity (KOGUT, 2000; NANG et al., 2011; QUINTEIRO-FILHO et al., 2017).
Produced cytokines are classified into profiles according to the major kind of cytokine, which is guided by the antigen nature, for instance, if they are from an extracellular pathogen or from an intracellular pathogen (KAISER, 2010). In general, intracellular pathogens elicit higher production of interferon gamma (IFN- $\gamma$ ) (GURJAR et al., 2013) and interleukin-2 (IL-2), and this profile is named Th1 (SANTHAKUMAR et al., 2017). After an infection by an extracellular pathogen, the cytokine polarization is featured by the production of IL-4 and IL-5 cytokines, this is named Th2 (DEGEN et al., 2005).

The other crucial lymphocyte population is the B cells, which are featured as APC and antibody producing cell (Figure 2) (XIAO et al., 2017). The $\mathrm{B}$ cells are not MHC-restricted lymphocytes and hence are able to capture soluble antigens. Following the entrapment of the antigen, the $\mathrm{B}$ cells begin a clonal expansion. These cells are then differentiated into plasma cells which are the "antibody factories" (Figure 2) (TAEBIPOUR et al., 2017).

Antibodies are antigen binding proteins that are highly specific and sensitive to the antigenic target (ARNOLD \& CHUNG, 2018). Avian immune

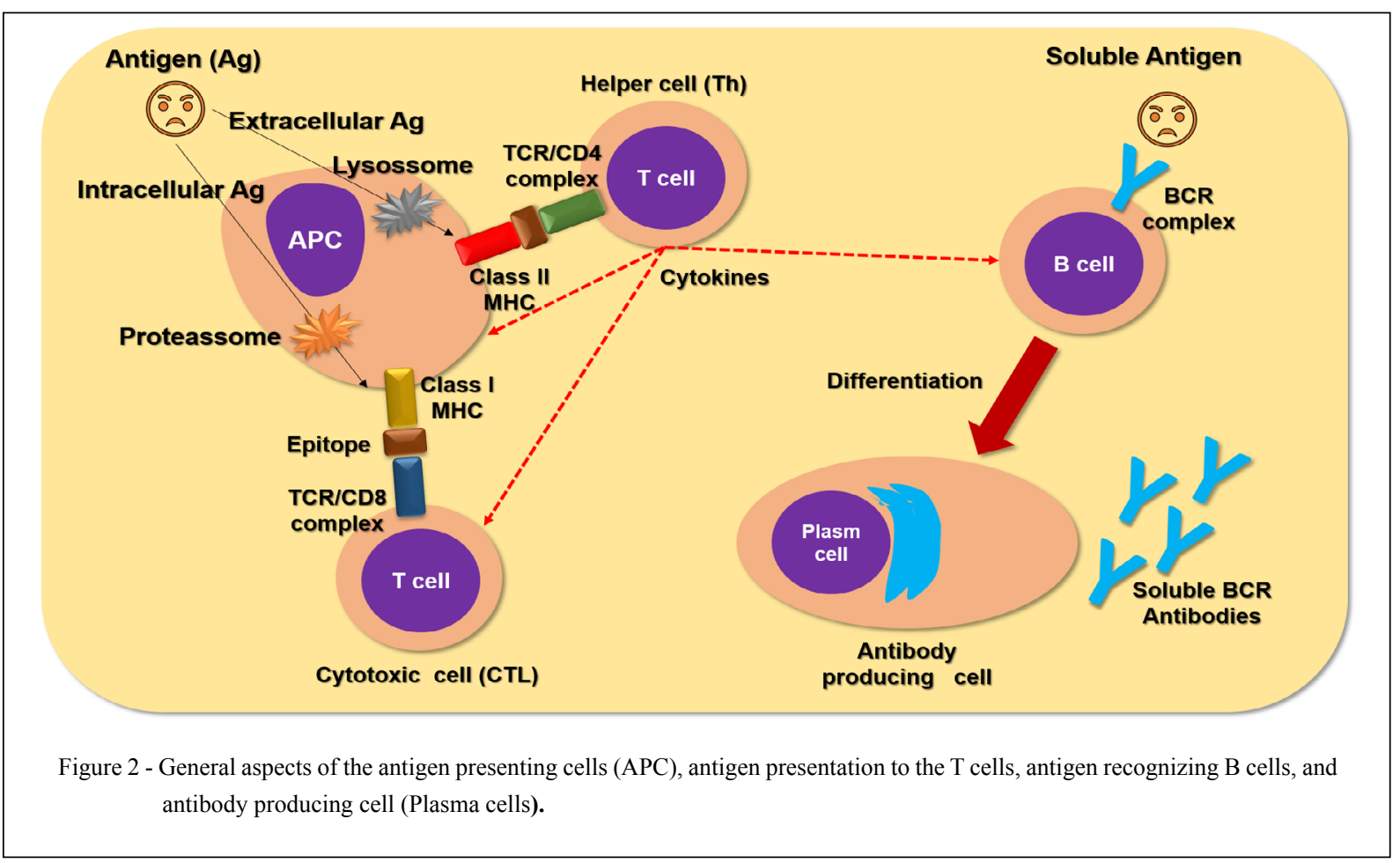

Ciência Rural, v.48, n.8, 2018. 
response has been described to possess three antibody classes; immunoglobulin $\mathrm{M}(\operatorname{IgM}), \operatorname{IgA}$, and $\operatorname{IgY}$ (Figure 1) (SMIALEK et al., 2011; ZHANG et al., 2017), while the mammals' immune system has five antibody classes; IgM, IgA, IgG, IgE, and IgD.

IgY antibody shares structural similarities with mammalian IgG, like the antigen binding fragment (Fab) with complementarity determining regions (CDR) and crystallizable fragments $(\mathrm{Fc})$. However, IgY antibody lacks a hinge region and has a longer heavy chain. Additionally, IgY does not binding to mammal's Fc receptor, rheumatoid factor or proteins of complement $(\mathrm{C} 1 \mathrm{q}$ and $\mathrm{C} 3)$. Together, these features are able preventing the occurrence of false positive findings in diagnostic platforms and make IgY a suitable innovation as an immunereagent (LEE et al., 2017).

According to the type of antigen (t-dependent or $\mathrm{t}$-independent) that immune system reacts, the predominant immunocompetent cells and the antibody class, the immune response can be classified as a primary or secondary immune response (GURJAR et al., 2013). The primary immune response is characterized by predominately IgM producing cells rather than $\mathrm{IgY} / \mathrm{IgG}$ with an incipient immune memory. Conversely, the secondary immune response has a higher production of IgY/IgG and the development of a solid immune memory (MEUNIER et al., 2017; OU et al., 2017).

Maternal IgY or IgG antibodiesbased newborn protection is crucial for avian and mammal species, respectively (LEANDRO et al., 2011). However, the transference of these maternal antibodies has been established by different pathway comparing hens and mammals. Transference of $\operatorname{IgY}$ antibodies occurs by their translocation into the egg yolk, while mammal's transplacental passage has been demonstrated for IgG antibodies (LEANDRO et al., 2011; MERRILL \& GRINDSTAFF, 2014; BERNARDINI et al., 2017).

The egg yolk is concentrated daily into the hens' ovarian follicle by the translocation of compounds from hens' blood molecules. Among these are proteins such as the IgY antibodies (Figure 3). The egg yolk IgY deposition follows a circadian rhythm with five day intervals between the passage of higher and lower IgY concentrations (HE et al., 2014).

The IgY antibodies are easily extracted from the egg yolk and the process does not require a bleeding procedure on hens. Also, among the many advantages of IgY is their antigen binding repertoire, which is achieved by gene conversion using the

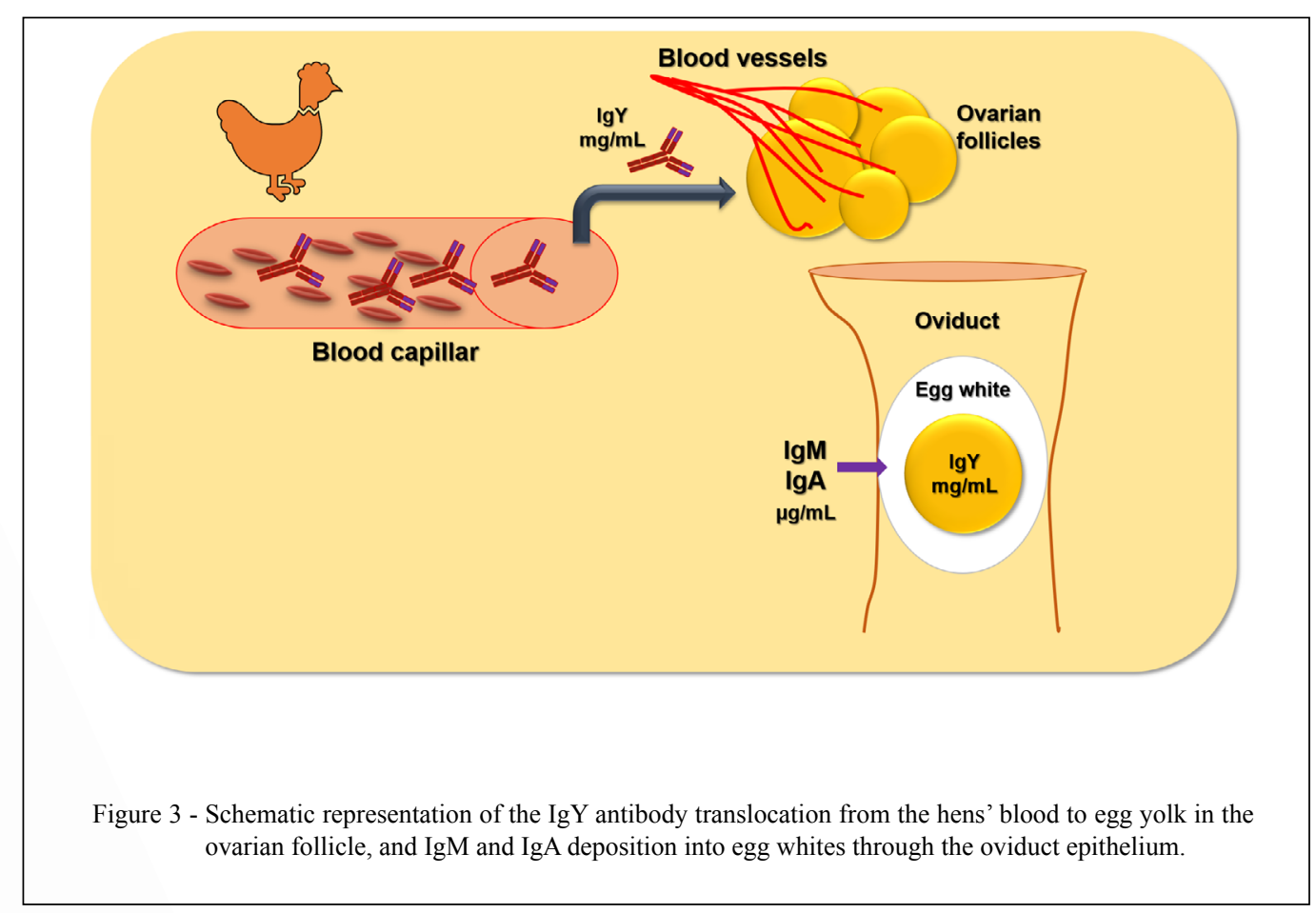

Ciência Rural, v.48, n.8, 2018. 
insertion of segments from pseudogenes (KAISER, 2012); their avidity maturation; the propensity to avoid false positive results in the mammalian model of immunoassay platforms; enzyme and fluorescence antibody conjugation; immune-gold beads antibody labeling, and the production of monoclonal antibodies, such as single chain fragment variable $(\mathrm{scFv})$ by cloning the fragment antigen binding (Fab) coding genes from the hen $\mathrm{B}$ cell (FERREIRA JÚNIOR et al., 2012; NIE et al., 2014; ZHANG et al., 2016; DA ROCHA et al., 2017; BORGES et al., 2018).

\section{CONCLUSION}

The avian immune system has been demonstrated to be highly competent, with a robust innate and acquired immune response against different kinds of pathogens. In this context, IgY antibodies are a crucial character in the hens' immune response due to their specific antigen-binding properties. Hence, it has a wide range application as an immunobiological reagent.

\section{ACKNOWLEDGEMENTS}

The authors wish to thank the Coordenação de Aperfeiçoamento de Pessoal de Nível Superior (CAPES, Brasil), Fundação de Amparo à Pesquisa de Minas Gerais (FAPEMIG) e Instituto de Estudos Avançados em Medicina Veterinária "José Caetano Borges" (UNIUBE) for granting a finnancial support to the present review in the field of IgY-technology.

\section{DECLARATION OF CONFLICTING OF INTERESTS}

The authors declare no conflict of interest. The founding sponsors had no role in the design of the study; in the collection, analyses, or interpretation of data; in the writing of the manuscript, and in the decision to publish the results.

\section{REFERENCES}

ARNOLD, K. B.; CHUNG, A. W. Prospects from systems serology research. Immunology, v. 153, n. 3, p.279-289, Mar 2018. ISSN 1365-2567. Available from: <https://www.ncbi.nlm.nih.gov/ pubmed/29139548>.

ARUN, K. V.; TALWAR, A.; KUMAR, T. S. T-helper cells in the etiopathogenesis of periodontal disease: A mini review. J Indian Soc Periodontol, v. 15, n. 1, p. 4-10, Jan 2011. ISSN 0975-1580. Available from: $<$ https://www.ncbi.nlm.nih.gov/pubmed/21772714>.

BECKER, Y. Immunological and regulatory functions of uninfected and virus infected immature and mature subtypes of dendritic cells--a review. Virus Genes, v. 26, n. 2, p. 119-30, 2003. ISSN 0920-8569. Available from: <https://www.ncbi.nlm.nih.gov/ pubmed/12803463>.

BERNARDINI, R. et al. Neonatal protection and preterm birth reduction following maternal group $\mathrm{B}$ streptococcus vaccination in a mouse model. J Matern Fetal Neonatal Med, v. 30, n. 23, p.
2844-2850, Dec 2017. ISSN 1476-4954. Available from: <https:// www.ncbi.nlm.nih.gov/pubmed/27973991>.

BLUM, J. S.; WEARSCH, P. A.; CRESSWELL, P. Pathways of antigen processing. Annu Rev Immunol, v. 31, p. 443-73, 2013. ISSN 1545-3278. Available from: <https:/www.ncbi.nlm.nih.gov/ pubmed/23298205>.

BOEHM, T.; HESS, I.; SWANN, J. B. Evolution of lymphoid tissues. Trends Immunol, v. 33, n. 6, p. 315-21, Jun 2012. ISSN 1471-4981. Available from: $<$ https://www.ncbi.nlm.nih.gov/pubmed/22483556>.

BORGES, I. P. et al. Antiparasitic effects induced by polyclonal IgY antibodies anti-phospholipase A. Int J Biol Macromol, v. 112, p. 333342, Jan 2018. ISSN 1879-0003. Available from: <https://www.ncbi. nlm.nih.gov/pubmed/29391226>.

BÍLKOVÁ, B. et al. Different breeds, different blood: Cytometric analysis of whole blood cellular composition in chicken breeds. Vet Immunol Immunopathol, v. 188, p. 71-77, Jun 2017. ISSN 1873-2534. Available from: < https://www.ncbi.nlm.nih.gov/pubmed/28615130>.

DA ROCHA, D. G. et al. The complementarity-determining region sequences in IgY antivenom hypervariable regions. Data Brief, v. 13, p. 717-722, Aug 2017. ISSN 2352-3409. Available from: $<\mathrm{https} / /$ www.ncbi.nlm.nih.gov/pubmed/28748206>.

DE GEUS, E. D.; VERVELDE, L. Regulation of macrophage and dendritic cell function by pathogens and through immunomodulation in the avian mucosa. Dev Comp Immunol, v. 41, n. 3, p. 341-51, Nov 2013. ISSN 1879-0089. Available from: <http://www.ncbi.nlm. nih.gov/pubmed/23542704>.

DEGEN, W. G. et al. Th1/Th2 polarization by viral and helminth infection in birds. Vet Microbiol, v. 105, n. 3-4, p. 163-7, Feb 2005. ISSN 0378-1135. Available from: <https://www.ncbi.nlm.nih.gov/ pubmed/15708812>.

FERREIRA JÚNIOR, Á. et al. Production, characterization and applications for Toxoplasma gondii-specific polyclonal chicken egg yolk immunoglobulins. PLoS One, v. 7, n. 7, p. e40391, 2012. ISSN 1932-6203. Available from: <http://www.ncbi.nlm. nih.gov/pubmed/22808150>.

GRUEBER, C. E.; WALLIS, G. P.; JAMIESON, I. G. Episodic positive selection in the evolution of avian toll-like receptor innate immunity genes. PLoS One, v. 9, n. 3, p. e89632, 2014. ISSN 1932-6203. Available from: < https://www.ncbi.nlm.nih. gov/pubmed/24595315>.

GUO, X. et al. Molecular mechanisms of primary and secondary mucosal immunity using avian infectious bronchitis virus as a model system. Vet Immunol Immunopathol, v. 121, n. 3-4, p. 332-43, Feb 2008. ISSN 0165-2427. Available from: <https:// www.ncbi.nlm.nih.gov/pubmed/17983666>.

GURJAR, R. S.; GULley, S. L.; VAN GINKEL, F. W. Cellmediated immune responses in the head-associated lymphoid tissues induced to a live attenuated avian coronavirus vaccine. Dev Comp Immunol, v. 41, n. 4, p. 715-22, Dec 2013. ISSN 1879-0089. Available from: <https://www.ncbi.nlm.nih.gov/ pubmed/23948147>.

HASSELGREN, P. O.; FISCHER, J. E. The ubiquitin-proteasome pathway: review of a novel intracellular mechanism of muscle protein breakdown during sepsis and other catabolic conditions. Ann Surg, v. 225, n. 3, p. 307-16, Mar 1997. ISSN 0003-4932. Available from: <https://www.ncbi.nlm.nih.gov/pubmed/9060588>. 
HE, J. X. et al. Chronobiological studies of chicken IgY: monitoring of infradian, circadian and ultradian rhythms of IgY in blood and yolk of chickens. Vet Immunol Immunopathol, v. 160, n. 3-4, p. 266-72, Aug 2014. ISSN 1873-2534. Available from: <https:// www.ncbi.nlm.nih.gov/pubmed/24998020>.

HEIDARI, M.; FITZGERALD, S. D.; ZHANG, H. Immune Responses in Cecal Tonsils of Marek's Disease Virus-Infected Chickens. Avian Dis, v. 59, n. 2, p. 213-26, Jun 2015. ISSN 0005-2086. Available from: <https:/www.ncbi.nlm.nih.gov/ pubmed/26473671>.

IFRAH, M. E. et al. The role of the bursa of Fabricius in the immune response to vaccinal antigens and the development of immune tolerance in chicks (Gallus domesticus) vaccinated at a very young age. Poult Sci, v. 96, n. 1, p. 51-57, Jan 2017. ISSN 1525-3171. Available from: <https:/www.ncbi.nlm.nih.gov/ pubmed/27418658>.

JEURISSEN, S. H. et al. Defence mechanisms against viral infection in poultry: a review. Vet Q, v. 22, n. 4, p. 204-8, Oct 2000. ISSN 0165-2176. Available from: <https:/www.ncbi.nlm.nih.gov/ pubmed/11087131>.

KAISER, P. Advances in avian immunology--prospects for disease control: a review. Avian Pathol, v. 39, n. 5, p. 309-24, Oct 2010. ISSN 1465-3338. Available from: <https://www.ncbi.nlm. nih.gov/pubmed/20954007>.

KAISER, P. The long view: a bright past, a brighter future? Forty years of chicken immunology pre- and post-genome. Avian Pathol, v. 41, n. 6, p. 511-8, Dec 2012. ISSN 1465-3338. Available from: <https://www.ncbi.nlm.nih.gov/pubmed/23237363>.

KAUFMAN, J. The simple chicken major histocompatibility complex: life and death in the face of pathogens and vaccines. Philos Trans R Soc Lond B Biol Sci, v. 355, n. 1400, p. 1077-84, Aug 2000. ISSN 0962-8436. Available from: <https://www.ncbi.nlm. nih.gov/pubmed/11186309>.

KAUFMAN, J. Co-evolution with chicken class I genes. Immunol Rev, v. 267, n. 1, p. 56-71, Sep 2015. ISSN 1600-065X. Available from: <https://www.ncbi.nlm.nih.gov/pubmed/26284471>.

KOGUT, M. H. Cytokines and prevention of infectious diseases in poultry: a review. Avian Pathol, v. 29, n. 5, p. 395-404, Oct 2000. ISSN 1465-3338. Available from: <https://www.ncbi.nlm.nih.gov/ pubmed/19184830>.

LANNING, D. K.; KNIGHT, K. L. Diversification of the Primary Antibody Repertoire by AID-Mediated Gene Conversion. Results Probl Cell Differ, v. 57, p. 279-93, 2015. ISSN 0080-1844. Available from: $<$ https://www.ncbi.nlm.nih.gov/pubmed/26537386>.

LEANDRO, N. M. et al. Maternal antibody transfer to broiler progeny varies among strains and is affected by grain source and cage density. Poult Sci, v. 90, n. 12, p. 2730-9, Dec 2011. ISSN 0032-5791. Available from: <https://www.ncbi.nlm.nih.gov/ pubmed/22080011>.

LEE, W. et al. Insights into the chicken IgY with emphasis on the generation and applications of chicken recombinant monoclonal antibodies. J Immunol Methods, v. 447, p. 71-85, 082017. ISSN 1872-7905. Available from: <https:/www.ncbi.nlm.nih.gov/ pubmed/28502720>

LIVERSIDGE, J.; FORRESTER, J. V. Antigen processing and presentation in the eye: a review. Curr Eye Res, v. 11 Suppl, p. 49-58,
1992. ISSN 0271-3683. Available from: <https://www.ncbi.nlm. nih.gov/pubmed/1424751>.

MADEJ, J. P.; STEFANIAK, T.; BEDNARCZYK, M. Effect of in ovo-delivered prebiotics and synbiotics on lymphoid-organs' morphology in chickens. Poult Sci, v. 94, n. 6, p. 1209-19, Jun 2015. ISSN 0032-5791. Available from: <https://www.ncbi.nlm.nih.gov/ pubmed/25877410>.

MELIEF, C. J. Mini-review: Regulation of cytotoxic T lymphocyte responses by dendritic cells: peaceful coexistence of cross-priming and direct priming? Eur J Immunol, v. 33, n. 10, p. 2645-54, Oct 2003. ISSN 0014-2980. Available from: <https://www.ncbi.nlm. nih.gov/pubmed/14515248>.

MERRILL, L.; GRINDSTAFF, J. L. Maternal antibody transfer can lead to suppression of humoral immunity in developing zebra finches (Taeniopygia guttata). Physiol Biochem Zool, v. 87, n. 5, p. 740-51, 2014 Sep-Oct 2014. ISSN 1537-5293. Available from: $<$ https://www.ncbi.nlm.nih.gov/pubmed/25244385>.

MEUNIER, M. et al. Promising new vaccine candidates against Campylobacter in broilers. PLoS One, v. 12, n. 11, p. e0188472, 2017. ISSN 1932-6203. Available from: <https://www.ncbi.nlm. nih.gov/pubmed/29176789>.

MILLER, M. M.; TAYLOR, R. L. Brief review of the chicken Major Histocompatibility Complex: the genes, their distribution on chromosome 16, and their contributions to disease resistance. Poult Sci, v. 95, n. 2, p. 375-92, Feb 2016. ISSN 0032-5791. Available from: <https://www.ncbi.nlm.nih.gov/pubmed/26740135>.

MUKHERJEE, S.; KARMAKAR, S.; BABU, S. P. TLR2 and TLR4 mediated host immune responses in major infectious diseases: a review. Braz J Infect Dis, v. 20, n. 2, p. 193-204, 2016 Mar-Apr 2016. ISSN 1678-4391. Available from <https://www. ncbi.nlm.nih.gov/pubmed/26775799>.

NAGY, N.; BÓDI, I.; OLÁH, I. Avian dendritic cells: Phenotype and ontogeny in lymphoid organs. Dev Comp Immunol, v. 58, p. 47-59, May 2016. ISSN 1879-0089. Available from: <https://www. ncbi.nlm.nih.gov/pubmed/26751596>.

NANG, N. T. et al. Induction of inflammatory cytokines and Tolllike receptors in chickens infected with avian H9N2 influenza virus. Vet Res, v. 42, p. 64, May 2011. ISSN 1297-9716. Available from: <https://www.ncbi.nlm.nih.gov/pubmed/21592354>.

NIE, G. et al. Detection of Clonorchis sinensis circulating antigen in sera from Chinese patients by immunomagnetic bead ELISA based on IgY. PLoS One, v. 9, n. 12, p. e113208, 2014. ISSN 1932-6203. Available from: <https://www.ncbi.nlm.nih.gov/ pubmed/25474577>.

$\mathrm{OU}, \mathrm{H}$. et al. Longevity of protective immune responses induced by a split influenza A (H7N9) vaccine mixed with MF59 adjuvant in BALB/c mice. Oncotarget, v. 8, n. 54, p. 91828-91840, Nov 2017. ISSN 1949-2553. Available from: <https://www.ncbi.nlm. nih.gov/pubmed/29190879>.

PARKER, A.; KAUFMAN, J. What chickens might tell us about the MHC class II system. Curr Opin Immunol, v. 46, p. 23-29, Jun 2017. ISSN 1879-0372. Available from: <https://www.ncbi. nlm.nih.gov/pubmed/28433952>.

PEI, J.; COLLISSON, E. W. Specific antibody secreting cells from chickens can be detected by three days and memory B cells by three weeks post-infection with the avian respiratory corona- 
virus. Dev Comp Immunol, v. 29, n. 2, p. 153-60, 2005. ISSN 0145-305X. Available from: <https://www.ncbi.nlm.nih.gov/ pubmed/15450755>.

QUINTEIRO-FILHO, W. M. et al. Heat stress decreases expression of the cytokines, avian $\beta$-defensins 4 and 6 and Toll-like receptor 2 in broiler chickens infected with Salmonella Enteritidis. Vet Immunol Immunopathol, v. 186, p. 19-28, Apr 2017. ISSN 1873-2534. Available from: <https://www.ncbi.nlm.nih.gov/ pubmed/28413046>.

QURESHI, M. A.; HEGGEN, C. L.; HUSSAIN, I. Avian macrophage: effector functions in health and disease. Dev Comp Immunol, v. 24, n. 2-3, p. 103-19, 2000 Mar-Apr 2000. ISSN 0145-305X. Available from: <https://www.ncbi.nlm.nih.gov/ pubmed/10717282>.

ROSTAMI, H. et al. Supplementing dietary rosemary (Rosmarinus officinalis L.) powder and vitamin $\mathrm{E}$ in broiler chickens: evaluation of humoral immune response, lymphoid organs, and blood proteins. Environ Sci Pollut Res Int, Jan 2018. ISSN 1614-7499. Available from: <https://www.ncbi.nlm.nih.gov/pubmed/29330815>.

SANTHAKUMAR, D. et al. Avian Interferons and Their Antiviral Effectors. Front Immunol, v. 8, p. 49, 2017. ISSN 1664-3224. Available from: <https://www.ncbi.nlm.nih.gov/pubmed/28197148>.

SCHADE, R. et al. Chicken egg yolk antibodies, production and application. IgY-Technology. . $1^{\text {st }}$ 2001. 255.

SEPAHI, A.; SALINAS, I. The evolution of nasal immune systems in vertebrates. Mol Immunol, v. 69, p. 131-8, Jan 2016. ISSN 1872-9142. Available from: <https://www.ncbi.nlm.nih.gov/pubmed/26391349>.

SHARMA, J. M.; TIZARD, I. Avian cellular immune effector mechanisms--a review. Avian Pathol, v. 13, n. 3, p. 357-76, Jul 1984. ISSN 0307-9457. Available from: <https://www.ncbi.nlm.nih.gov/ pubmed/18766854>

SINGH, S. et al. Avian influenza viral nucleocapsid and hemagglutinin proteins induce chicken CD8+ memory T lymphocytes. Virology, v. 399, n. 2, p. 231-8, Apr 2010. ISSN 1096-0341. Available from: $<$ https://www.ncbi.nlm.nih.gov/pubmed/20116819>.

SMIAŁEK, M. et al. Local immunity of the respiratory mucosal system in chickens and turkeys. Pol J Vet Sci, v. 14, n. 2, p. 291-7, 2011 ISSN 1505-1773. Available from: <https://www.ncbi.nlm.nih.gov/ pubmed/21721419>.
SUN, H. et al. Thymus transcriptome reveals novel pathways in response to avian pathogenic Escherichia coli infection. Poult Sci, v. 95 , n. 12 , p. 2803-2814, Dec 2016. ISSN 1525-3171. Available from: <https://www.ncbi.nlm.nih.gov/pubmed/27466434>.

TAEBIPOUR, M. J. et al. Evaluation of blood monocyte and lymphocyte population in broiler chicken after vaccination and experimental challenge with Newcastle disease virus. Vet Immunol Immunopathol, v. 190, p. 31-38, Aug 2017. ISSN 1873-2534. Available from: <https://www.ncbi.nlm.nih.gov/pubmed/28778320>.

VAN GINKEL, F. W. et al. Conjunctiva-associated lymphoid tissue in avian mucosal immunity. Dev Comp Immunol, v. 36, n. 2, p. 289-97, Feb 2012. ISSN 1879-0089. Available from: <https:// www.ncbi.nlm.nih.gov/pubmed/21641931>.

WANG, Y. et al. Review on the identification and role of Toxoplasma gondii antigenic epitopes. Parasitol Res, v. 115, n. 2, p. 459-68, Feb 2016. ISSN 1432-1955. Available from: <https:// www.ncbi.nlm.nih.gov/pubmed/26581372>.

XIAO, J. et al. Conserved peptides enhance immune efficiency of inactive vaccines against emerging avian influenza viruses in chicken. Sci China Life Sci, v. 60, n. 12, p. 1340-1347, Dec 2017. ISSN 1869-1889. Available from: <https://www.ncbi.nlm.nih.gov/ pubmed/29230639>.

YOSHIMURA, Y.; BARUA, A. Female Reproductive System and Immunology. Adv Exp Med Biol, v. 1001, p. 33-57, 2017. ISSN 0065-2598. Available from: <https://www.ncbi.nlm.nih.gov/ pubmed $/ 28980228>$.

ZHANG, Q. et al. Identification and structural composition of the blood-spleen barrier in chickens. Vet J, v. 204, n. 1, p. 110-6, Apr 2015. ISSN 1532-2971. Available from: <https://www.ncbi.nlm. nih.gov/pubmed/25779339>.

ZHANG, X. et al. IgY: a key isotype in antibody evolution. Biol Rev Camb Philos Soc, v. 92, n. 4, p. 2144-2156, Nov 2017. ISSN 1469-185X. Available from: <https://www.ncbi.nlm.nih.gov/ pubmed/28299878>

ZHANG, X. et al. IgY: Preparation of chicken IgY against recombinant E2 protein of bovine viral diarrhea virus (BVDV) and development of ELISA and ICA for BVDV detection. Biosci Biotechnol Biochem, v. 80 , n. 12, p. 2467-2472, Dec 2016. ISSN 1347-6947. Available from: <https://www.ncbi.nlm.nih.gov/ pubmed/27484991> 